\title{
Melatonin and the seasonal control of reproduction
}

\author{
Benoît Malpaux*, Jean-Claude Thiéry, Philippe Chemineau
}

\author{
Laboratoire de neuroendocrinologie sexuelle, Inra, PRMD, \\ URA CNRS 1291, 37380 Nouzilly, France
}

(Received 1 March 1999; accepted 16 April 1999)

\begin{abstract}
Many mammalian species from temperate latitudes exhibit seasonal variations in breeding activity which are controlled by the annual photoperiodic cycle. Photoperiodic information is conveyed through several neural relays from the retina to the pineal gland where the light signal is trans lated into a daily cycle of melatonin secretion: high at night, low in the day. The length of the nocturnal secretion of melatonin reflects the duration of the night and it regulates the pulsatile secretion of gonadotropin-releasing hormone $(\mathrm{GnRH})$ from the hypothalamus. Changes in $\mathrm{GnRH}$ release induce corresponding changes in luteinising hormone secretion which are responsible for the alternating presence or absence of ovulation in the female, and varying sperm production in the male. It is not yet known where and how this pineal indoleamine acts to exert this effect. Although melatonin binding sites are preferentially localised in the pars tuberalis (PT) of the adenohypophysis, the hypothalamus contains the physiological target sites of melatonin for its action on reproduction. Melatonin does not seem to act directly on GnRH neurons; rather it appears to involve a complex neural circuit of interneurons that includes at least dopaminergic, serotoninergic and excitatory aminoacidergic neurons. (C) Inra/Elsevier, Paris
\end{abstract}

\section{melatonin / reproduction / photoperiod / prolactin / dopamine}

Résumé - La mélatonine et le contrôle saisonnier de la reproduction. Un grand nombre de mammifères originaires des latitudes tempérées présentent des variations saisonnières d'activité sexuelle qui sont sous le contrôle du cycle photopériodique annuel. L'information photopériodique transite par plusieurs relais de la rétine à la glande pinéale où le signal lumineux est traduit en rythme nycthéméral de sécrétion de mélatonine : élevée le jour, faible la nuit. La durée de sécrétion nocturne de mélatonine est proportionnelle à la durée de la nuit et contrôle la sécrétion pulsatile de gonadotropin releasing hormone (GnRH). Les changements de libération de $\mathrm{GnRH}$ induisent des variations correspondantes de sécrétion d'hormone lutéinisante qui à leur tour sont responsables de l'alternance entre périodes ovulatoire et anovulatoire chez la femelle et des variations de production spermatique chez le mâle. Les sites et les mécanismes d'action de la mélatonine qui sont responsables de ces effets ne sont pas connus avec précision. Bien que les sites de liaison de la mélatonine soient localisés préférentiellement dans la pars tuberalis (PT) de l'hypophyse antérieure, l'hypothalamus contient les

\footnotetext{
* Correspondence and reprints

E-mail: malpaux@tours.inra.fr
} 
cibles physiologiques de la mélatonine pour son action sur la reproduction. La mélatonine ne semble pas agir directement sur les neurones à GnRH. Au contraire, son action implique un circuit complexe d'interneurones qui inclut au moins des neurones dopaminergiques, sérotoninergiques et à acides aminés excitateurs. ㅇ Inra/Elsevier, Paris

\section{mélatonine / photopériode / reproduction / hypothalamus / dopamine}

\section{INTRODUCTION}

In temperate zones, many mammalian species display a seasonal pattern of reproduction [7]. Depending on the time of year when they are sexually active, species are characterised as short-day breeders, for instance sheep, or long-day breeders, for instance hamsters or horses. The pineal hormone, melatonin, through its nocturnal mode of secretion, has been shown to be the primary transducer of photoperiodic information to the neuroendocrine reproductive axis $[1,2]$. The importance of the pineal gland was demonstrated by numerous experiments showing that the effect of photoperiod on seasonal functions is profoundly altered in pinealectomised animals. In Syrian hamsters, pinealectomy prevents the seasonal reduction in gonadotropin secretion and the gonadal regression normally brought about by experimental or natural short photoperiod [55]. Injection of melatonin reverses the effect of pinealectomy on gonadotropin secretion and causes gonadal regression. This early work, mainly in the hamster, led to the concept of the antigonadal action of melatonin. However, more recent data, particularly those obtained in short-day breeders have led to a more generalised role of melatonin in the control of seasonal rhythms $[26,27,29]$. Specifically, pinealectomy suppresses responses to both short and long photoperiod, and melatonin, depending on its specific pattern, reinstates both these responses. Thus, the role of melatonin is to provide an endocrine code for daylength. This role was well illustrated by replacement studies in pinealectomised animals.
Melatonin delivered into the peripheral circulation to mimic short-day or long-day profiles can reproduce the stimulatory effects of short days or the inhibitory ones of long days on LH secretion in the ewe [29].

\section{GnRH NEURONS AS THE FINAL NERVOUS PATHWAY OF MELATONIN ACTION}

The duration of melatonin secretion is processed neurally to regulate the secretion of GnRH. The final step of the action of melatonin at the level of the central nervous system is a modulation of GnRH secretion, partly as a consequence of the modification of steroid feedback. Melatonin treatment causes an increase in the immunoreactivity of GnRH in cell bodies located in the hypothalamus and increased density of GnRH-containing elements in the median eminence, in addition to its suppressive effects on gonadal function in white-footed mice [17, 18]. In Djungurian hamsters, a rapid and transient increase in the distribution of detectable GnRH mRNA-containing cells is observed 2 days after transfer to stimulatory long days. This increase may be an early step in the stimulation of FSH secretion and gonadal growth which occur days later [3]. In sheep, it is possible to measure directly and reliably the release of GnRH in the hypophyseal portal system [9], and melatonin, given as a short-day profile, causes an increase in the frequency of pulsatile GnRH release ([69], figure 1). This increase in GnRH secretion is observed after a long lag time, i.e. 40-60 days, when LH 


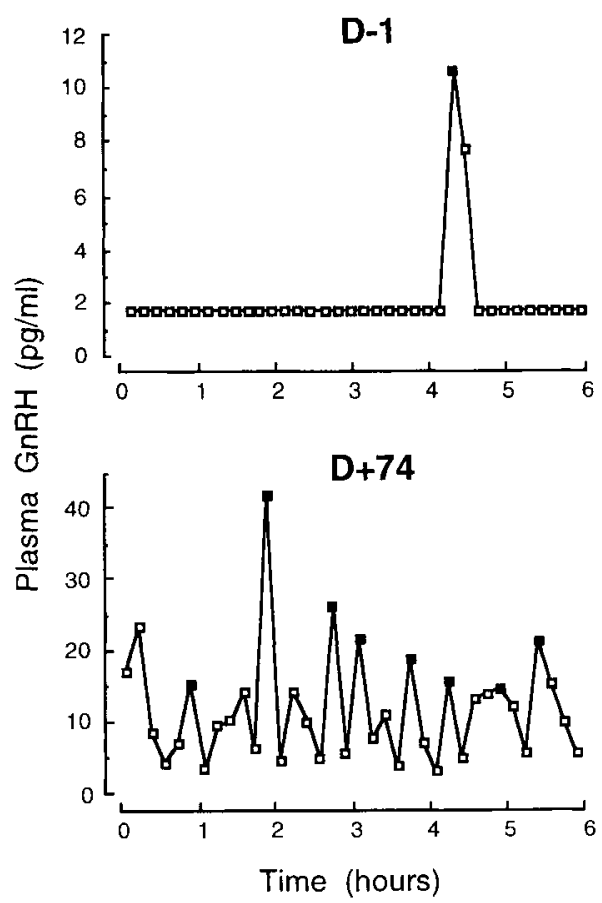

Figure 1. Effect of melatonin on GnRH pulsatile secretion. Examples of individual profiles of GnRH secretions before (D -1, top) or 74 days after (bottom) the insertion of a melatonin implant. Ewes were ovariectomised and treated with a subcutaneous estradiol implant and were exposed to long days (16L:8D). Blood samples were obtained every $10 \mathrm{~min}$ for $6 \mathrm{~h}$ on each occasion. The closed symbols depict detected pulses (adapted from [69]).

secretion is stimulated. Despite this effect of melatonin on the GnRH system, it is thought that melatonin does not act directly on the GnRH neurons; rather it acts indirectly through some interneuronal route that finally synapses on the GnRH neurons. The changes in GnRH secretion are the consequences of two complementary mechanisms controlled by melatonin [53]: a direct steroidindependent modulation of $\mathrm{GnRH}$ secretion and a change in the steroid negative feedback on GnRH secretion. For example, in ovariectomised (OVX) ewes, LH pulse frequency is lower in animals treated with a long-day profile of melatonin than with a short-day one (one versus two pulses per hour) $[51,57]$. This change in LH pulsatility between these two situations is increased dramatically when OVX ewes are treated with estradiol (E). Indeed, in OVX ewes treated with an $\mathrm{E}$ implant that elevates blood $E$ levels to those of follicular phase intact ewes, one pulse is observed every 12-24 h in long days and every $30 \mathrm{~min}$ in short days [29].

\section{SITES OF ACTION OF MELATONIN}

The identification of the sites of action of melatonin is difficult since melatonin influences many physiological functions [1]. Melatonin could either act at a single site in the brain or pituitary which would then be implicated in the regulation of many seasonal functions, or melatonin could act at multiple sites, each involved in regulating one seasonal function. This difficulty is expanded by the localisation of high-affinity melatonin receptors in a wide variety of tissues in the body, although whether melatonin acting at these sites could affect seasonal functions remains debatable $[5,6,52$, 59].

The first demonstration that melatonin acted in the brain was provided by studies in the white-footed mouse. Small beeswax pellets impregnated with melatonin and implanted in the anterior hypothalamus and medial preoptic area cause gonadal regression similar to that induced by short days. Pellets placed in other areas of the brain and subcutaneously have no effect on the gonads [19]. Interestingly, similar results were obtained with a rhythmic pattern of intracerebral melatonin delivery. Melatonin delivered for $10 \mathrm{~h}$, but not $5 \mathrm{~h}$, in the anterior hypothalamus or medial preoptic area causes gonadal regression of pinealectomised white-footed mice [13]. Similar results were obtained in Djungurian hamsters and gerbils $[12,22]$. However, these studies could not define a precise target within the brain. 
A major breakthrough was made with the development of the melatonin probe, ${ }^{125}$ I-melatonin which allowed identification of putative target sites of melatonin within the hypothalamo-hypophyseal system whose importance was then tested by functional studies, mainly in hamsters and sheep. Although binding was found in several areas within the brain and the pituitary $[6,11,68]$, it was the pars tuberalis that drew most attention since the density of binding was much higher than in any other hypothalamic or pituitary site and because it is a consistent feature among species investigated to date. Several studies have also found a seasonal variation in the melatonin binding site density and in the cytology of the pars tuberalis $[15,58]$. Finally, the pars tuberalis is in a prime anatomical position for interacting with both the median eminence and the pars distalis of the pituitary and could, therefore, influence hypothalamohypophyseal function.

Surprisingly, studies in sheep and hamsters have led to the conclusion that the pars tuberalis does not mediate the action of melatonin on the neuroendocrine reproductive axis. Indeed, in the ewe, melatonin delivered directly to the PT does not appear to modify the secretion of LH: neither the placement of a melatonin microimplant directly against the anterior face of the PT [43] nor the discrete insertion of a microimplant into the PT [46] modified LH secretion. In contrast, microimplants placed in the $\mathrm{MBH}$ or third ventricle stimulated $\mathrm{LH}$ release $[43,46]$. These studies provide definitive evidence that the hypothalamus, and not the PT, is the important melatonin target for transducing the effects of this indoleamine on the reproductive neuroendocrine axis. Moreover, the placement of microimplants in the PT or pars distalis of Soay rams led to similar conclusions [41]. In that study, PT microimplants stimulated FSH secretion but the effect was much weaker than that obtained with $\mathrm{MBH}$ implants in a previous study, suggesting that the small effect observed with the PT implants resulted from a passive diffusion of melatonin to the $\mathrm{MBH}[39,41]$. In this species, melatonin binding was found in the premammillary hypothalamic area: it is located at the base of the brain and limited dorsally by the fornix; it extends $3 \mathrm{~mm}$ on either side of the third ventricle, is posterior to the infundibular recess, and is delimited caudally by the mammillary bodies ([10, 44], figure 2). A clear relationship was observed between the proximity of melatonin microimplants to the area of binding and the effectiveness of these microimplants to stimulate $\mathrm{LH}$, strongly suggesting that melatonin targets are located in the premammillary hypothalamic area [44]. In hamsters, the hypothalamic localisation of the target sites of melatonin for acting on reproduction was also strongly suggested. Lesions of the dorsomedial hypothalamus melatonin binding sites block the gonadotropic response of male Syrian hamsters to short photoperiod or melatonin [48]. Furthermore, an overlap between melatonin binding and androgen receptor immunoreactivity is found in the dorsomedial nucleus and it was suggested that sensitivity to steroid feedback, a key mechanisms of the action of melatonin on gonadotropin secre-

Figure 2. Coronal sections of sheep hypothalamus illustrating distribution of melatonin binding sites. Top to bottom reflects rostral to caudal sequence (1-5). Left column (A): cresyl violet-stained sections; middle column (B): autoradiographic image of total iodomelatonin binding; right column (C): non-specific binding, estimated by incubating adjacent section with a 200 -fold excess of cold melatonin. Note the specific binding of melatonin in the pars tuberalis (B1 and B2) and in the premammillary hypothalamic area (B3 and B4). Nomenclature: V: third ventricle; FMT: fasciculus mamillothalamicus; Fx: fornix; TO: tractus opticus; CM: corpus mamillare; EM: median eminence; PT: pars tuberalis (from [44]). 

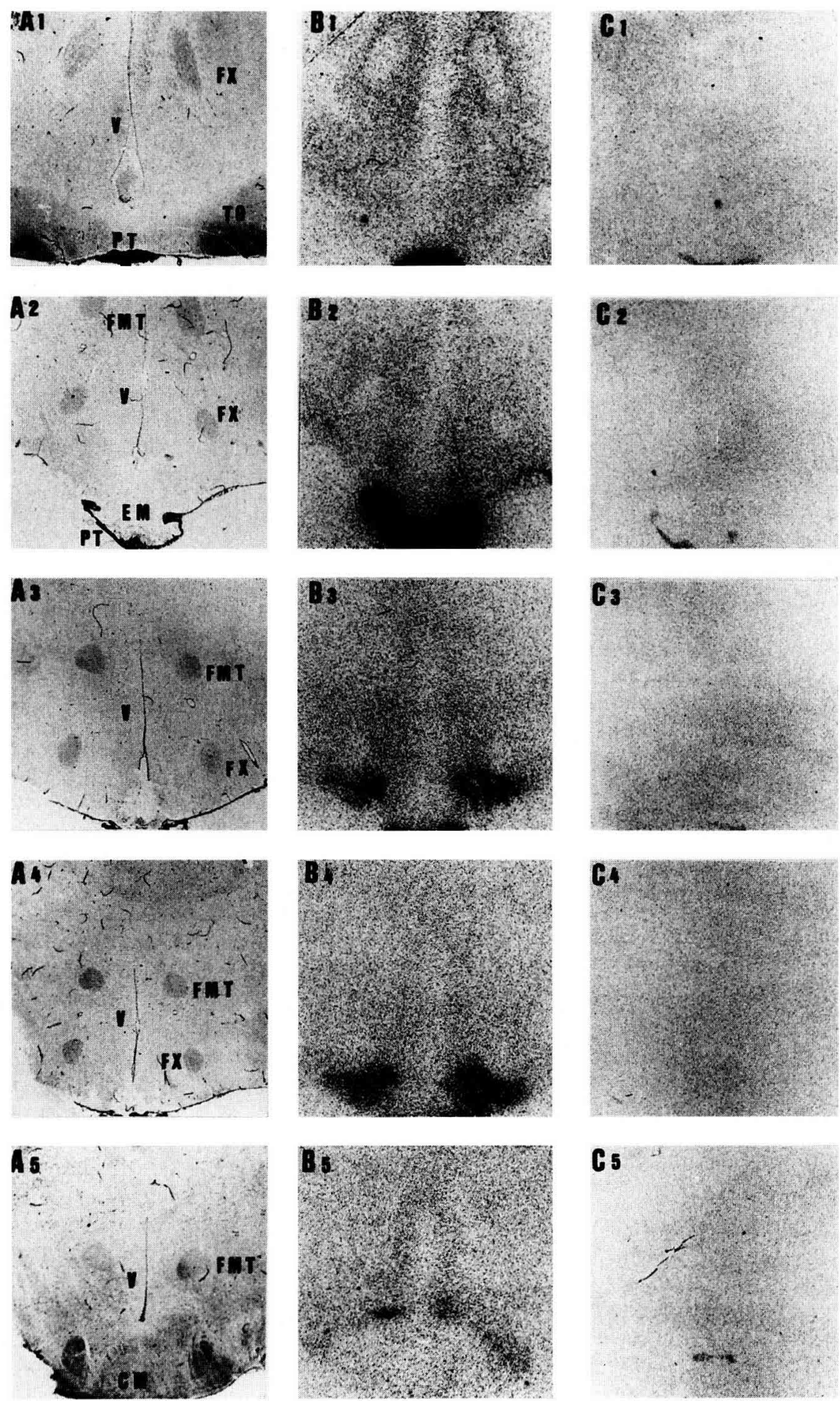
tion, might be influenced in this area in Syrian hamsters [47]. Although it remains to be established whether the areas identified in hamsters and sheep are functionally related, these data suggest a discrete target for melatonin in the hypothalamus.

The pars tuberalis mediates, at least in part, the action of melatonin on prolactin secretion. Indeed, in the ewe, melatonin implants inserted within the pars tuberalis, have an inhibitory effect on prolactin release [46]. Also, in rams with a surgical hypothalamo-pituitary disconnection in which the central control of prolactin secretion is abolished, the ability of melatonin to inhibit the secretion of prolactin is maintained [40]. Interestingly, in hamsters, lesion of the melatonin binding sites in the medial basal hypothalamus suppresses the effect of melatonin on the reproductive axis, but does not do so on prolactin secretion [48].

The dual site of action of melatonin for controlling gonadotropin and prolactin secretion is interesting in relation to the photoperiodic regulation of these two functions. Indeed, the action of photoperiod and melatonin on reproductive activity is characterised by long latency and the importance of photoperiodic history which is consistent with an action at the level of the brain for the storage of information. In contrast, photoperiodic history is not critical to the regulation of prolactin secretion [21] and the action of melatonin is relatively rapid (only a few days [73]) which is consistent with a more 'classical' endocrine regulation at the level of the pituitary. This regulation could involve tuberalin, a putative protein produced by the target cells of melatonin, that would influence gene expression and secretion in lactotrophs [25].

In mammals, two subtypes of high affinity G-protein-coupled melatonin receptors have been cloned (Mel-1A and Mel-1B) [56]. The high level of expression of these receptors in the pars tuberalis suggests that they mediate the action of melatonin on prolactin secretion. In contrast, the photore- sponsiveness of hamsters in which the Mel-1B receptor gene cannot encode a functional receptor [74] and the failure to obtain a strong expression of these receptors in the hypothalamus outside of the suprachiasmatic nucleus raise the question of the type of melatonin receptors involved in the control of reproductive activity.

\section{INTERNEURONS BETWEEN MELATONIN TARGET NEURONS AND GnRH NEURONS}

Several pieces of evidence suggest that melatonin does not act directly on GnRH neurons. First, the distribution of most GnRH neurons does not match that of the putative sites of action of melatonin. In sheep, most GnRH neuronal perikarya are located in the preoptic area $(60 \%)$ with a few located in the $\mathrm{MBH}(15 \%)$; some of these project to the median eminence and abut portal vessels $[8,38]$; no GnRH neurons were identified in the pre mammillary area. Second, a large number of neurotransmitters are involved in the regulation of the GnRH neurons and constitute potential candidates to mediate the effects of melatonin on GnRH release. Indeed, experimental evidence implicating several neuronal systems has been obtained.

\subsection{Dopamine}

Many studies have suggested that dopamine is involved in transducing the negative feedback of $E$ on GnRH secretion. For instance, systemic injection of a dopamine antagonist (pimozide) during anoestrus (strong negative feedback of $\mathrm{E}$ ) induced a temporary increase in LH secretion [49]. Similarly, pimozide caused a temporary increase in LH secretion in long-day exposed (photo-inhibited) OVX + E ewes [33]. The A15 hypothalamic cell group appears to be a key dopaminergic structure involved in mediating the inhibitory effects of $E$ since a neurotoxic lesion of this struc- 
ture during anoestrus caused an increase in LH secretion [64]. Furthermore, it has been shown that $\mathrm{E}$ increases tyrosine hyroxylase ( $\mathrm{TH}$, rate limiting step enzyme of catecholamine synthesis) activity in long-day treated ewes [16] and induces c-fos gene expression in TH-immunoreactive cells of this structure in a season-dependent manner [36]. A similar role has been proposed for the A14 dopaminergic cell group [24]. Since a major effect of melatonin is a modulation of E negative feedback on GnRH secretion, this implication of dopamine makes these neurons likely candidates to act as relays between melatonin target sites and GnRH neurons [63].

In order to test this hypothesis, we first determined whether photoperiod and melatonin could modulate the activity of some dopaminergic neurons in the hypothalamus. Exposure to stimulatory short days resulted in decreased dopaminergic activity in the median eminence as assessed both by a reduction in dopamine content and in $\mathrm{TH}$ activity $[62,72]$. No effect of short-day exposure on noradrenaline content in this structure or on $\mathrm{TH}$ activity in the other hypothalamic areas investigated was found [72]. The stimulation of LH secretion by a melatonin implant caused a parallel reduction in $\mathrm{TH}$ activity which suggests strongly that the effect of photoperiod on TH activity is mediated by melatonin [73]. The inhibition of median eminence $\mathrm{TH}$ activity by short days or by treatment with a melatonin implant is expressed at a time when the inhibition of prolactin secretion is already maximal, suggesting that these photoperiod-induced changes in TH activity are independent of the regulation of prolactin secretion [73]. Rather, they appear to be related to the photoperiodic regulation of $\mathrm{LH}$ secretion. Indeed, the pharmacological blockade of $\mathrm{TH}$ locally in the median eminence of ewes treated with 35 long days led to an increase in LH secretion [71]. This finding is consistent with the effect of pimozide implants in the median eminence of anoestrous ewes [23]. Interestingly, the pharmacological blockade of TH activity no longer causes a stimulation of LH secretion when it is applied after a longer exposure to long days ( 71 days [4]). These data suggest, therefore, that an increase in TH activity in the median eminence is an important component of the inhibitory effect of long-day melatonin profile on GnRH output, at least for the initial phase of the inhibition. However, such modulation of TH activity appears to be E-independent because the photoperiod-induced changes in $\mathrm{TH}$ activity are similar in OVX and OVX + E ewes [72]. Thus, in contrast to the A15 and possibly A14 dopaminergic nuclei, which are involved in the modulation of the $E$ negative feedback, the dopaminergic neurons of the median eminence appear to be involved upstream relative to the integration of the $\mathrm{E}$ signal. The median eminence in sheep is a structure rich in dopaminergic terminals but contains no TH-immunoreactive perikarya [65]. The localisation of the cell bodies projecting their axons to the median eminence, and more generally the anatomical and functional relationship between the A14 and A15 nuclei and the median eminence, have yet to be determined.

In male Syrian hamsters, exposure to inhibitory short days, presumably through melatonin secretion, reduces dopamine and noradrenaline turnover in the median eminence $[60,61]$. This change is associated with a decrease in L-aromatic amino acid decarboxylase-positive cells in the arcuate nucleus without changes in $\mathrm{TH}$-immunoreactive cell number or TH activity $[31,32]$. Suppression of LH and FSH release in this species is presumably related to reduced noradrenaline activity, whereas reduced dopamine turnover may represent a consequence of suppression of prolactin levels by short days $[60,61]$.

\subsection{Serotonin}

Evidence for the implication of serotonin was also obtained in sheep. Serotonin inhibits LH pulsatile secretion during seasonal 
anoestrus, and not during the breeding season $[33,50]$. This inhibitory effect of serotonin is mediated by $5-\mathrm{HT} 2$, receptors [34] and interestingly a photoperiod-induced change in the density of $5-\mathrm{HT} 2$, receptors in the ventrolateral posterior hypothalamus was described [35, 54].

\subsection{Excitatory amino acids}

The implication of excitatory amino acids in the photoperiodic regulation of LH secretion was suggested by experiments involving administration of N-methyl-D,L-aspartic acid (NMDA), an agonist of neuroexcitatory amino acids. Such an administration acutely stimulates GnRH and LH secretion in seasonal species such as sheep and hamsters. However, this stimulatory effect is larger during periods of photoinhibited LH secretion than during photostimulated periods $[28,42,70]$. Also, in male hamsters, the inhibitory effect of short days on testicular activity can be blocked by chronic treatment with NMDA [66]. Although glutamate is involved in the photic regulation of circadian rhythm at the level of the retinohypothalamic tract, this action of NMDA cannot be explained by an effect on the melatonin secretory rhythm. Indeed, the differential effect of NMDA in photoinhibited and photostimulated ewes is maintained if stimulation is induced by melatonin administration instead of short-day exposure [70]. Furthermore, in Djungarian hamsters, the chronic effect of NMDA is observed on the photoperiod-induced changes in reproduction, but not on other functions (pelage colour, body weight [14]). These experiments suggest that a change in excitatory amino acid input may be part of the mechanism mediating the action of melatonin on GnRH secretion. Consistent with this hypothesis, photoperiod modifies the density of NMDA receptors in the preoptic area of hamsters [67].

Besides the neurotransmitters or receptors mentioned above, future research will probably reveal the involvement of other neuronal systems in mediating the action of melatonin on GnRH neurons. Regardless of the nature of these neurons, the action of melatonin on GnRH neurons most likely involves a complex network of interacting neurons.

Part of the mode of action of photoperiod could be to cause morphological changes in this neuronal network. Evidence for such an effect was obtained at the level of the GnRH neurons of the ewe. At the light microscopicy level, immunostained GnRH neurons in the preoptic area have longer and more numerous dendrites during anoestrus than during the breeding season [38]. However, these changes could reflect alterations in the content or localisation of immunodetectable GnRH, rather than actual morphological changes. At the electron microscopicy level, GnRH neurons in the preoptic area receive more than twice the mean number of synaptic inputs per unit of plasma membrane during the breeding season as during anoestrus $[37,75]$. Interestingly, these changes are not dependent on changes in ovarian steroid levels which differs markedly with the examples of seasonal plasticity described in the literature due to changing levels of steroids. The changes observed in the preoptic area of the ewe could, therefore, reflect the action of photoperiod and melatonin, or the expression of the circannual rhythm of reproduction, a key element of the photoperiod responsive mechanisms in this species [45].

In relation to possible phenomena of neuronal plasticity, it is worth noting that thyroid hormones have been strongly implicated in allowing seasonal changes in reproductive activity [30]. Reproductive transition from the breeding season to anoestrus is dependent upon the presence of thyroid hormones. Thyroidectomised ewes do not exhibit a seasonal decline in episodic secretion of GnRH in hypophyseal portal blood and thus fail to enter anoestrus. Thyroxine replacement reverses the effect of 
thyroidectomy and the seasonal changes in thyroid hormone concentrations are not necessary for this reversal [30]. Since thyroid hormones are essential for the normal morphological maturation of the central nervous system [20], the permissive role of thyroid hormones for seasonal changes to occur may be to cause the prerequired morphological rearrangements for the changes in GnRH secretion.

\section{CONCLUSION}

The regulation of GnRH secretion by melatonin is central to the photoperiodic regulation of reproductive activity. The target sites of melatonin appear to be located in the hypothalamus but their precise localisation (at a cellular level) and their neurotransmitter phenotype have yet to be determined. Melatonin does not act directly on GnRH neurons; rather its action is probably mediated by a complex network of interneurons. The identification of the elements of this network and their inter-relationship will enable us to understand the long-term mechanisms that melatonin uses to control GnRH secretion.

\section{REFERENCES}

[1] Arendt J., Melatonin and the Mammalian Pineal Gland, Chapman \& Hall, London, 1995, 331 p.

[2] Bartness T.J., Powers J.B., Hastings M.H., Bittman E.L., Goldman B.D., The timed infusion paradigm for melatonin delivery: what has it taught us about the melatonin signal, its reception, and the photoperiodic control of seasonal responses?, J. Pineal Res. 15 (1993) 161-190.

[3] Bernard D.J., Abuav-Nussbaum R., Horton T.H., Turek F.W., Photoperiodic effects on gonadotropin-releasing hormone ( $\mathrm{GnRH})$ content and the GnRH-immunoreactive neuronal system of male siberian hamsters, Biol. Reprod. 60 (1999) 272-276.

[4] Bertrand F., Viguié C., Picard S., Malpaux B., Median eminence dopaminergic activation is critical for the early long-day inhibition of luteinizing hormone secretion in the ewe, Endocrinology 139 (1998) 5094-5102.
[5] Bittman E.L, The sites and consequences of melatonin binding in mammals, Am. Zool. 33 (1993) 200-211.

[6] Bittman E.L., Weaver D.R., The distribution of melatonin binding sites in neuroendocrine tissues of the ewe, Biol. Reprod. 43 (1990) 986-993.

[7] Bronson F.H., Mammalian Reproductive Biology, The University of Chicago Press, Chicago, 1989.

[8] Caldani M., Batailler M., Thiéry J.C., Dubois M.P., LH-RH immunoreactive structures in the sheep brain, Histochemistry 89 (1988) 129-139.

[9] Caraty A., Evans N.P., Fabre-Nys C.J., Karsch F.J., The preovulatory gonadotrophinreleasing hormone surge: a neuroendocrine signal for ovulation, J. Reprod. Fertil. Suppl. 49 (1995) 245-255

[10] Chabot V., Caldani M., de Reviers M.M., Pelletier J., Localisation and quantification of melatonin receptors in the diencephalon and posterior telencephalon of the sheep brain, J. Pineal Res. 24 (1998) 50-57.

[11] de Reviers M.-M., Ravault J.-P., Tillet Y., Pelletier J., Melatonin binding sites in the sheep pars tuberalis, Neurosci. Lett. 100 (1989) 89-93.

[12] Devries M.J., Ferreira S.A., Glass J.D., Evidence that short photoperiod-induced gonadal regression in the Mongolian gerbil is mediated by the action of melatonin in the medial hypothalamus, Brain Res. 494 (1989) 241-246.

[13] Dowell S.F., Lynch G.R., Duration of the melatonin pulse in the hypothalamus controls testicular function in pinealectomised mice (Peromyscus leucopus), Biol. Reprod. 36 (1997) 1095-1101.

[14] Ebling F.J., Alexander I.H., Urbanski H.F., Hastings M.H., Effects of N-methyl-D-aspartate (NMDA) on seasonal cycles of reproduction, body weight and pelage colour in the male Siberian hamster, J. Neuroendocrinol. 7 (1995) 555-566.

[15] Gauer F., Masson-Pevet M., Saboureau M. George D., Pevet P., Differential seasonal regulation of melatonin receptor density in the pars tuberalis and the suprachiasmatic nuclei: a study in the hedgehog (Erinaceus europaeus, L.), Neuroendocrinology 5 (1993) 685-690.

[16] Gayrard V., Malpaux B., Tillet Y., Thiéry J.C., Estradiol increases tyrosine hydroxylase activity of the A15 nucleus dopaminergic neurons during long days in the ewe, Biol. Reprod. 50 (1994) 1168-1177.

[17] Glass J.D., Short photoperiod-induced gonadal regression: effects on the gonadotropin-releasing hormone ( $\mathrm{GnRH}$ ) neuronal system of the whitefooted mouse, Peromyscus leucopus, Biol. Reprod. 35 (1986) 733-743.

[18] Glass J.D., Knotts L.K., A brain site for the antigonadal action of melatonin in the whitefooted mouse (Peromyscus leucopus): involvement of the immunoreactive GnRH neuronal system, Neuroendocrinology 46 (1987) 48-55. 
[19] Glass J.D., Lynch G.R., Evidence for a brain site of melatonin action in the white-footed mouse, Peromyscus leucopus, Neuroendocrinology 34 (1982) 1-6.

[20] Granholm A.C., Effects of thyroid hormone deficiency on glial constituents in developing cerebellum of the rat, Exp. Brain Res. 59 (1985) 451-456.

[21] Hastings M.H., Walker A.P., Powers J.B., Hutchison J., Steel E.A., Herbert J., Differential effects of photoperiodic history on the responses of gonadotrophins and prolactin to intermediate daylengths in the male Syrian hamster, J. Biol. Rhythms 4 (1989) 335-350.

[22] Hastings M.H., Walker A.P., Roberts A.C., Herbert J., Intra-hypothalamic melatonin blocks photoperiodic responsiveness in the male Syrian hamster, Neuroscience 24 (1988) 987-991.

[23] Havern R.L., Whisnant C.S., Goodman R.L., Hypothalamic sites of catecholamine inhibition of luteinizing hormone in the anoestrous ewe, Biol. Reprod. 44 (1991) 476-482.

[24] Havern R.L., Whisnant C.S., Goodman R.L., Dopaminergic structures in the ovine hypothalamus mediating estradiol negative feedback in anoestrous ewes, Endocrinology 134 (1994) 1905-1914.

[25] Hazlerigg D.G., Hastings M.H., Morgan P.J., Production of a prolactin releasing factor by the ovine pars tuberalis, J. Neuroendocrinol. 8 (1996) 489-492.

[26] Herbert J., The pineal gland and photoperiodic control of the ferret's reproductive cycle, in: Follett B.K., Follett D.E. (Eds.), Biological Clocks in Seasonal Reproduction, Wright, Bristol, 1981, pp. 261-276.

[27] Hoffman K., Photoperiodism in vertebrates, in: Aschoff J. (Ed.), Handbook of Behavioural Neurobiology, 1981, pp. 449-473.

[28] Hui Y., Hastings M.H., Maywood E.S., Ebling F.J., Photoperiodic regulation of glutamatergic stimulation of secretion of luteinizing hormone in male Syrian hamsters, J. Reprod. Fertil. 95 (1992) 935-946.

[29] Karsch F.J., Bittman E.L., Foster D.L., Goodman R.L., Legan S.J., Robinson J.E., Neuroendocrine basis of seasonal reproduction, Recent Prog. Horm. Res. 40 (1984) 185-232.

[30] Karsch F.J., Dahl G.E., Hachigian T.M., Thrun L.A., Involvement of thyroid hormones in seasonal reproduction, J. Reprod. Fertil. Suppl. 49 (1995) 409-422.

[31] Krajnak K., Manzanares J., Lookingland K.J., Nunez A.A., The effect of short-photoperiod exposure on tuberoinfundibular dopamine neurons in male and female Syrian hamsters, J. Biol. Rhythms 9 (1994) 125-135.

[32] Krajnak K., Nunez A.A., Short-photoperiod exposure reduces $\mathbf{L}$-aromatic-amino-acid decarboxylase immunostaining in the arcuate nucleus and median eminence of male Syrian hamsters, Brain Res. 712 (1996) 95-101.
[33] Le Corre S., Chemineau P., Control of photoperiodic inhibition of luteinizing hormone secretion by dopaminergic and serotoninergic systems in ovariectomised Ile-de-France ewes supplemented with oestradiol, J. Reprod. Fertil. 97 (1993) 367-373.

[34] Le Corre S., Chemineau P., Serotonergic 5HT2 receptors mediate the inhibitory action of serotonin on luteinizing hormone secretion in ovariectomised, estradiol-treated ewes that are refractory to short days, Biol Reprod. 49 (1993) 140-147.

[35] Le Corre S., Segu L., Caldani M., Chemineau P., Differences in ketanserin binding in the ventromedial hypothalamus of ewes responsive or refractory to short days, Neuroendocrinology 60 (1994) 589-600.

[36] Lehman M.N., Durham D.M., Jansen H.T., Adrian B.A., Goodman R.L., Dopaminergic A 14/A15 neurons are activated during estradiol negative feedback in anoestrous, but not in breeding season, ewes, Endocrinology 137 (1996) 4443-4450.

[37] Lehman M.N., Goodman R.L., Karsch F.J., Jackson G.L., Berriman S.J., Jansen H.T., The GnRH system of seasonal breeders: anatomy and plasticity, Brain Res. Bull. 44 (1997) 445-457.

[38] Lehman M.N., Robinson J.E., Karsch F.J., Silverman A.J., Immunocy tochemical localisation of luteinizing hormone-releasing hormone (LHRH) pathways in the sheep brain during anoestrus and the mid-luteal phase of the estrous cycle, J. Comp. Neurol. 244 ( 1986) 19-35.

[39] Lincoln G.A., Effects of placing micro-implants of melatonin in the pars tuberalis, pars distalis and the lateral septum of the forebrain on the secretion of FSH and prolactin, and testicular size in rams, J. Endocrinol. 142 (1994) 267-276.

[40] Lincoln G.A., Clarke I.J., Photoperiodicallyinduced cycles in the secretion of prolactin in hypothalamo-pituitary disconnected rams: evidence for translation of the melatonin signal in the pituitary gland, J. Neuroendocrinol. 6 (1994) 251-260.

[41] Lincoln G.A., Maeda K.I., Reproductive effects of placing microimplants of melatonin in the mediobasal hypothalamus and preoptic area in rams, J. Endocrinol. 132 (1992) 201-215.

[42] Lincoln G.A., Wu F.C.W., Luteinizing hormone response to $\mathrm{N}$-methyl-D,L-aspartate during a photoperiodically-induced reproductive cycle in the ram, J. Neuroendocrinol. 3 (1991) 309-317.

[43] Malpaux B., Daveau A., Maurice F., Locatelli A., Thiéry J.C., Evidence that melatonin binding sites in the pars tuberalis do not mediate the photoperiodic actions of melatonin on LH and prolactin secretion in ewes, J. Reprod. Fert. 101 (1994) 625-632.

[44] Malpaux B., Daveau A., Maurice-Mandon F., Duarte G., Chemineau P., Evidence that mela- 
tonin acts in the premammillary hypothalamic area to control reproduction in the ewe: presence of binding sites and stimulation of luteinizing hormone secretion by in situ microimplant delivery, Endocrinology 139 (1998) 1508-1516.

[45] Malpaux B., Robinson J.E., Wayne N.L., Karsch F.J., Regulation of the onset of the breeding season of the ewe: importance of longs days and of an endogenous reproductive rhythm, J. Endocr. 122 (1989) 269-278.

[46] Malpaux B., Skinner D.C., Maurice F. The ovine pars tuberalis does not appear to be targeted by melatonin to modulate luteinizing hormone secretion, but may be important for prolactin release, J. Neuroendocrinol. 7 (1995) 199-206.

[47] Maywood E.S., Bittman E.L., Hastings M.H., Lesions of the melatonin- and androgen-responsive tissue of the dorsomedial nucleus of the hypothalamus block the gonadal response of male Syrian hamster to programmed infusions of melatonin, Biol. Reprod. 54 (1996) 470-477.

[48] Maywood E.S., Hastings M.H., Lesions of the iodomelatonin-binding sites of the mediobasal hypothalamus spare the lactotropic, but block the gonadotropic response of male Syrian hamsters to short photoperiod and to melatonin, Endocrinology 136 (1995) 144-153.

[49] Meyer S.L., Goodman R.L., Neurotransmitters involved in mediating the steroid-dependent suppression of pulsatile luteinizing hormone secretion in anoestrous ewes: effects of receptor antagonists, Endocrinology 116 (1985) 2054-2061.

[50] Meyer S.L., Goodman R.L., Separate neural systems mediate the steroid-dependent and steroidindependent suppression of tonic luteinizing hormone secretion in the anoestrous ewe, Biol. Reprod. 35 (1986) 562-571.

[51] Montgomery G.W., Martin G.B., Pelletier J., Changes in pulsatile LH secretion after ovariectomy in Ile-de-France ewes in two seasons, J. Reprod. Fertil. 73 (1985) 173-183.

[52] Morgan P.J., Barrett P., Howell H.E., Helliwell R., Melatonin receptors: localisation, molecular pharmacology and physiological significance, Neurochem. Int. 24 (2) (1994) 101-146

[53] Pelletier J., Ortavant R., Photoperiodic control of LH release in the ram. II. Light-androgens interaction, Acta Endocrinol. (Copenh.) 78 (1975) $442-450$.

[54] Pelletier J., Auzan C., Daveau A., Clauser E., Chemineau P., Sheep 5HT2A receptors: partial cloning of the coding sequence and mRNA localisation by in situ hybridization in the ewe hypothalamus, Cell Tissue Res. 295 (1999) 231-239.

[55] Reiter R.J., The pineal and its hormones in the control of reproduction in mammals, Endocr. Rev. 1 (1980) 109-131.

[56] Reppert S.M., Melatonin receptors: molecular biology of a new family of $G$ protein-coupled receptors, J. Biol. Rhythms 12 (1997) 528-531.
[57] Robinson J.E., Radford H.M., Karsch F.J., Seasonal changes in pulsatile luteinizing hormone (LH) secretion in the ewe, relationship of frequency of LH pulses to day length and response to estradiol negative feedback, Biol. Reprod. 33 (1985) 324-334.

[58] Rutten A., Hewing M., Wittkowski W., Seasonal ultrastructural changes of the hypophyseal pars tuberalis in the hedgehog (Erinaceus europaeus L.), Acta Anat. (Basel) 133 (1988) 217-223.

[59] Stankov B., Cozzi B., Lucini V., Scaglione F., Fraschini F., Characterization and mapping of melatonin receptors in the brain of three mammalian species rabbit, horse and sheep, Neuroendocrinology 53 (1991) 214-221.

[60] Steger R.W., Bartke A., Temporal sequence of neuroendocrine events associated with the transfer of male golden hamsters from a stimulatory to a nonstimulatory photoperiod, Biol. Reprod. 44 (1991) 76-82.

[61] Steger R.W., Juszczak M., Fadden C., Bartke A., Photoperiod effects on neurohypophyseal and tuberoinfundibular dopamine metabolism in the male hamster, Endocrinology 136 (1995) 3000-3006.

[62] Thiéry J.C., Monoamine content of the stalkmedian eminence and hypothalamus in adult female sheep as affected by daylength, J. Neuroendocrinol. 3 (1991) 407-411.

[63] Thiéry J.C., Gayrard V., Le Corre S., Viguié C., Martin G.B., Chemineau P., Malpaux B., Dopaminergic control of LH secretion by the A15 nucleus in anoestrous ewes, J. Reprod. Fertil. Suppl. 49 (1995) 285-296.

[64] Thiéry J.C., Martin G.B., Tillet Y., Caldani M., Quentin M., Jamain C., Ravault J.P., Role of hypothalamic catecholamines in the regulation of luteinizing hormone and prolactin secretion in the ewe during seasonal anoestrus, Neuroendocrinology 49 (1989) 80-87.

[65] Tillet Y., Distribution of neurotransmitters in the sheep brain, J. Reprod. Fertil. Suppl. 49 (1995) 199-220.

[66] Urbanski H.F., Fahy M.M., Collins P.M., Influence of N-methyl-D-aspartate on the reproductive axis of male Syrian hamsters, J. Endocrinol. 137 (1993) 247-252.

[67] Urbanski H.F., Pierce M., Photoperiodic control of seasonal breeding in Syrian hamsters: involvment of excitatory amino acid receptors, Neuroendocrinol. Lett. 14 (1991) 33-37.

[68] Vanecek J., Pavlik A., Illnerova H., Hypothalamic melatonin receptor sites revealed by autoradiography, Brain Res. 435 (1987) 359-362.

[69] Viguié C., Caraty A., Locatelli A., Malpaux B., Regulation of luteinizing hormone-releasing hormone (LHRH) secretion by melatonin in the ewe. I. Simultaneous delayed increase in LHRH and luteinizing hormone pulsatile secretion, Biol. Reprod. 52 (1995) 1114-1120. 
[70] Viguié C., Caraty A., Locatelli A., Malpanx B., Regulation of luteinizing hormone-releasing hormone (LHRH) secretion by melatonin in the ewe. II. Changes in N-methyl-D,L-aspartic acidinduced LHRH release during the stimulation of luteinizing hormone secretion by melatonin, Biol. Reprod. 52 (1995) 1156-1161.

[71] Viguié C., Picard S., Thiéry J.C., Malpaux B., Blockade of tyrosine hydroxylase activity in the median eminence partially reverses the long day-induced inhibition of pulsatile L.H secretion in the ewe, J. Neuroendocrinol. 10 (1998) 551-558.

[72] Viguié C., Thibault J., Thiéry J.C., Tillet Y., Malpaux B., Photoperiodic modulation of monoamines and amino-acids involved in the control of prolactin and $\mathrm{LH}$ secretion in the ewe: evidence for a regulation of tyrosine hydroxylase activity, J. Neuroendocrinol. 8 (1996) 465-474.
[73] Viguié C., Thibault J., Thiéry J.C., Tillet Y., Malpaux B., Characterization of short dayinduced decrease in median eminence tyrosine hydroxylase activity in the ewe: temporal relationship to the changes in luteinizing hormone and prolactin secretion and short-day like effect of melatonin, Endocrinology 138 (1997) 499-506.

[74] Weaver D.R., Liu C., Reppert S.M., Nature's knockout: the mellb receptor is not necessary for reproductive and circadian responses to melatonin in Siberian hamsters, Mol. Endocrinol. 10 (1996) 1478-1487.

[75] Xiong J.J., Karsch F.J., Lehman M.N., Evidence for seasonal plasticity in the gonadotropin-releasing hormone (GnRH) system of the ewe: changes in synaptic inputs onto GnRH neurons, Endocrinology 138 (1997) 1240-1250. 